DOI: $10.15838 / \mathrm{esc} / 2015.2 .38 .10$

UDC 316.728, LBC 60.526

(C) Kasimov R.A.

\title{
On the normative model of a healthy lifestyle
}

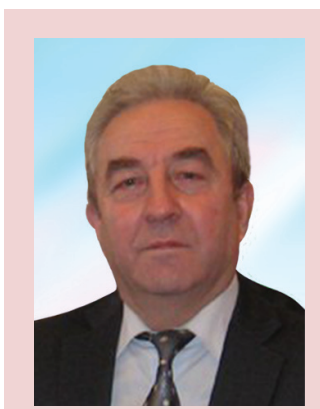

Riza Akhmedzakievich KASIMOV

Ph.D. in Pedagogy, Director, State Healthcare Institution "Vologda Oblast Center for Medical Prophylaxis” (9, Mira Street, Vologda, 160001, Russian Federation, vocmp-vologda@yandex.ru)

\begin{abstract}
The formation of a healthy lifestyle among the educational process subjects is one of the main functions of health-saving educational space. This function can be implemented effectively only if the executive bodies in the sphere of education, other agencies, the public and the subjects of the educational process take active part in this process. Such cooperation requires a common understanding in the issues to promote health of all pedagogical process participants, but to date the concept "healthy lifestyle" has not been clearly defined and the effective and optimized pedagogical models for its formation, according to the cross-cutting principle, have not been elaborated.

The article analyzes different points of view on this issue. A healthy lifestyle is considered as a complex pedagogical technology to create health culture. Taking into account the scholars' attitudes to the concept "healthy lifestyle" the author identifies three main components of a healthy lifestyle: health culture, health-saving activity and conditions that ensure a healthy lifestyle. The article argues that health saving needs of a person predetermine his/her health-saving activities. It reveals the main strategic sub-components of a healthy lifestyle: physical, environmental, medical, psychological and spiritual-moral activities. The work presents the normative model of a healthy lifestyle and its structure. It defines a healthy lifestyle as a model of health-saving behavior model. The author proves that the proposed normative model of a healthy lifestyle can be successfully used for the formation of health-saving educational space on the principles of inter-sectoral collaboration.
\end{abstract}

Key words: healthy way of life, healthy lifestyle, health culture, health-saving needs, physical activity, environmental activity, medical activity, mental activity, spiritual-moral, health-saving educational space. 


\section{Introduction}

At the present stage different interpretations of the concept "healthy lifestyle" do not lead to the efficient formation of health-saving educational space. It is necessary to define the key concept "healthy lifestyle" that would integrate the participants of the pedagogical process to create health-saving educational space not only as a general target, but as a single conceptual system that consolidates pedagogical potential of all the participants.

Starting from the variety of views on this concept, we should move to its single normative concept that involves reduction of this concept to the model (normative) norm adopted by all actors of healthsaving educational space in its uniform interpretation.

Many scientists of our time try to disclose the social nature of a lifestyle and its impact on health. However, their views on this issue as interdisciplinary differ.

Studying the essence of the concept "healthy lifestyle", one group of scientists presents it as rejection of harmful factors and approval of factors favorable for health (Yu.A. Andreeva, E.F. Solopov, B.N. Chumakov, etc.).

According to another group of scientists, this concept is reflected in social competence, a certain culture of healthy behavior (V. Kasatkin, Yu.P. Lisitsyn, V.M. Basova, etc.).

The third group of scientists believes that a healthy lifestyle is a certain pattern, an ideal of healthy behavior (L.N. Voloshina, I.Yu. Kokaeva, I.A. Korobeinikov, E.E. Chepurnykh, etc.).

The fourth group of scientists suggests that a healthy lifestyle can not be the same for everybody and comes to the conclusion that a healthy way of life at the individual level should be defined as a healthy lifestyle (S.O. Avchinnikova, M.Ya. Vilenskii, L.G. Tatarnikova, etc.). However, all the above views on the concept "healthy lifestyle" have common components to elaborate the normative model of a "healthy lifestyle".

\section{The core}

The health-saving educational space at any level is aimed at forming a healthy lifestyle of the educational process subjects, according to the principle of cooperation between specialists of different profiles. All participants of health-saving activities in the field of education should have common conceptual understanding of a healthy lifestyle.

In our view, a healthy lifestyle should be considered as a complex technology of healthy human life, which includes a number of interconnected sub-components of health-saving sub-components that require some effort for realization. It is necessary to identify the most important sub-components for maintaining and improving human health. This will simplify the conversion to a common norm of the studied concept.

L.N. Voloshina says that a "healthy lifestyle" is primarily a cultural way of life, civilized, humanistic"; she highlights the 
dependence of a healthy lifestyle of people's culture [5, p. 42].

According to "the Explanatory Dictionary of the Living Great Russian Language Russian language" by V. Dahl, culture is "education, intellectual and moral" [6, p. 217]. "Dictionary of the Russian Language" by S.I. Ozhegov treats culture as "a set of human achievements in industrial, public and mental regard" [12, p. 274].

Taking into account these interpretations we can conclude that cultural means educated, achieved certain combined knowledge, skills and abilities that are realized on the basis of moral and spiritual standards of life.

This statement gives grounds to consider health culture as a total of knowledge, skills and abilities in the field of healthy living, which are implemented in society as a healthy way of life. People's Commissar of Health N.A. Semashko writes: “... Without sanitary culture there can be no culture at all; without sanitary education there can not be healthy population..." Sanitary education is understood as "a set of educational, educational, advocacy and propaganda measures aimed at preserving, strengthening, rehabilitating health and labor ability of a person and extending his/her active life" [13, p. 199]. The main components forming a healthy way of life are presented in N.A. Semashko's statements. He considered sanitary culture as an end product of sanitary education. In our view, it is health culture; without it there can be no culture at all.
In the works of V.M. Basova, L.N. Voloshina, V.N. Kasatkina, V.V. Sokoreva and others health culture is revealed as social competence in terms of health preservation and strengthening.

So, we can single out one of the main components to define a healthy lifestyle health culture.

V.Z. Kogan emphasizes that the attitude to health is specifically manifested in actions and deeds, opinions and views of people regarding the factors influencing their physical and mental health. It can be adequate and inadequate due to its significance for people's life.

Thus, V.Z. Kogan puts forward a new approach to a healthy lifestyle and suggest taking into account the inner world of a person, its integral structure. He considers a person as a subject of health, who actively creates his/her physical, mental and social well-being, productive activity and creative longevity [8, p. 31].

Taking into account the inner world of a person, on the one hand, and active physical, mental and social well-being, on the other hand, V. Z. Kogan indicates the direct relationship of these phenomena and focuses on the fact that person's internal resources are key in his/her activity. The inclusion of person's inner potential in the formation of a healthy lifestyle seems important for the development of motivation to health-saving activities.

Thus, relating people's needs to their activities and health, we can consider their internal resources in terms of achievement of healthy lifestyle goals. Referring to this 
conclusion, we can also prove that human health depends on a person - the desire and activity to be healthy; person's needs predetermine the inclusion in a healthy lifestyle. This is one of the important components of a healthy lifestyle that encourages a person to satisfy them through a particular activity.

According to Yu.P. Lisitsyn, a healthy lifestyle is "a human activity focused on preservation and strengthening of health". Hence, people themselves are responsible for their physical, mental and social wellbeing; they possess certain knowledge, skills and abilities to preserve and promote their health; people should exercise a certain activity to achieve this goal. Thus, activity is another component of a healthy lifestyle.

According to V.K. Bal'sevich, physical activity should be considered as the "main sphere to form physical culture of a person". "Physical culture is the first, most natural bridge, connecting social and biological in man", he underlines [2, p. 22]. The relations between the activity and the cultural identity formation can be considered in terms of other kinds of human activity, which, like a mosaic, create person's culture. So, we can single out the method that, as an analogy, can be applied in the process to form a healthy lifestyle of the educational process subjects by training them in various types of activities.

A.I. Fedorov, S.B. Sharmanova consider a "healthy lifestyle" as a "typical set of forms and ways of life that promotes proper fulfilment of educational and labor, social and biological functions and is the important objective of school physical education" [17, p. 12]. The scientists especially highlight the integral part of a healthy lifestyle - physical activity, an "activity of an individual, aimed at achieving physical perfection" In our opinion, physical health of an individual can be achieved due to systematic physical activity. Physical perfection is rather a goal of those involved in professional sport. Optimal physical activity in order to maintain and promote health is a useful physical activity of a person, which can be attributed to one of the healthy lifestyle subcomponents. Hence, physical activity should be considered as optimized physical exercises, ensuring the preservation and strengthening of health.

The desire to give up bad habits also depends on the activity of man. We believe that the process to abandon unhealthy habits is part of the environmental activity to protect person's biological systems from external harmful factors, for example, from a large amount of alcohol, food, smoking, drugs, etc.

In the dictionary "Language of Newspapers, Radio, Television" by G.Ya. Solganik ecology is defined as a "science about the relationship between plants and animals and communities among them and the environment.

For example, human ecology, cultural ecology, etc." [14, p. 637]. The features of man's relationship with the environment are inherent in the definition. Environmental activity of people can be interpreted as 
their activities aimed at preventing and combating harmful environmental and behavioral factors. The biological systems of people are protected.

Yu.P. Lisitsyn defines a healthy lifestyle as an activity, which is most characteristic, typical for the specific socio-economic, political, environmental and other conditions aimed at preserving and strengthening people's health. He points out that the ways to form a healthy way of life derive from the understanding of its functional structure.

The key activity is medical, i.e. the activity of people associated with their and public health and aimed at protecting, strengthening, reproducing health positive health activity [11, p. 57] that should be nurtured from early childhood. Medical activity is divided into independent elements. This is health literacy, hygienic and unhygienic habits, visits to medical institutions for advice, following medical advice. He emphasizes that the exercise of medical activity depends largely on the general level of culture, education, attitudes, living conditions, state of healthcare, etc. Medical activity also includes the compliance with diet, physical culture and sports, attitude to smoking, alcohol, occupational health and safety compliance, etc.

In our opinion, these factors determining the way of life can be attributed to medical activity only in terms of following the doctor's advice. Medical activity, in our view, should be regarded as its activity to conserve and enhance people's health in collaboration with health services and as one of the sub-components of a healthy lifestyle. Yu.P. Lisitsyn's works are significant due to the identified components of a healthy lifestyle: medical and other activities, dependency on general culture of a person and other conditions.

A.A. Korobeinikov gives another definition of a healthy lifestyle. It is a "result of reasonable and moral human behavior, harmonious unity of body and spirit, existing in harmony with the laws of nature and society. This way of life is characterized by intellectual development, spiritual and moral wellbeing, physical strength, psychological soundness, opposition to antisocial habits, awareness of importance of physical and moral perfection, ability to harmonized interpersonal and social relations and on this basis - maximum realization of personal potential in the core areas of activity” [10, p. 69].

This definition highlights moral and psychological components of a person's lifestyle, which, in our opinion, is very important for the study of the concept nature. To realize spiritual, moral and psychological potential people should show some activity. This activity can be caused by spiritual, moral and psychological needs. So, there are two most important healthsaving subcomponents of a healthy life spiritual-moral and psychological activities.

Spiritual-moral activity of man can be defined as appropriate moral actions that 
satisfy spiritual needs and contribute to the preservation and strengthening of health.

In our view, psychological activity is an ability to implement actions aimed at overcoming and preventing stressful situations, ensuring the preservation and strengthening of health, as well as the harmonization of interpersonal and social relations.

A.A. Korobeinikov singles out such an important component of a healthy way of life, as psychological soundness. It depends on mental health of a person and has a different effect on his/her actions and different types of activities. Only psychological soundness can optimize all kinds of activities. Between human needs and corresponding activities there should exist psychological soundness, which ensures the optimization of this activity and, as a consequence, the efficiency of health maintenance. This conclusion is significant to reduce the concept "healthy lifestyle" to a single normative definition.

Having analyzed the works of V.K. Bal'sevich, V.Z. Kogan, A.A. Korobeinikov, Yu.P. Lisitsyn, A.I. Fedorov, we can single out the key sub-components of a healthy lifestyle: physical activity, medical activity, psychological and spiritual-moral activities.

L.G. Tatarnikova states that a "healthy lifestyle can not be the same for everybody, as people are natively different; therefore, to achieve a certain effect, they should behave differently".

Hence, she concludes: "Healthy is such a style (way of life), which leads to the desired expectancy and the quality demanded of life" [16, p. 23]. The style of behavior here can be viewed as the aggregate of individual human activities, which yields the desired results.

As there appears the concept "style of behavior", analogous to "lifestyle", it is necessary to understand the differences between the concepts "healthy way of life" and "healthy lifestyle". According to M.Ya. Vilenskii and S.O. Avchinnikova, the concepts of "way of life" and "lifestyle" should not be identified or opposed. They believe that the solution to this problem lies in the definition of subjects of the discussed phenomena. The creator of life activity forms that are of social nature is a subject of a way of life. The individual is a bearer of socially typical features of life activity; besides, he/she acts as a subject of his/her own lifestyle.

Hence, a lifestyle is not an integral part of a way of life, but embodiment of the latest at the individual level. They prove that a healthy lifestyle can be interpreted as individualized variant of a healthy way of life that includes ideological, behavioral and activity-based aspects. In the context of the stated above, they define a healthy lifestyle as a new formation of a person, a product of spiritual and physical effort, a comprehensive system of vital manifestations of a personality that contribute to the harmonization of his/ her individuality with the conditions of life and promote person's self-actualization [4, p. 2-7]. 
Assuming that this view of the concept "healthy lifestyle" coincides with ours, we will pursue to reveal the normative model of a healthy lifestyle. M.Ya. Vilenskii and S.O. Avchinnikova believe that to have a healthy lifestyle, a person has to show some effort, that is, a certain activity. The life manifestations, combined with the person's individuality express his/her vital needs. The integral system to satisfy the vital needs promoting people's healthy lifestyle discloses their culture. Thus, person's culture, which indicates the needs and determines the actions, i.e. types of activities, predetermines the lifestyle. The algorithm to transform culture to a healthy lifestyle can be the basis for an individual to lead a normative healthy lifestyle in the society.

The analysis of the scholars' views on the concept "healthy lifestyle" in terms of pedagogy, psychology and cultural studies, the study of a number of technologies of its formation lead to the following conclusions:

- all definitions of the term "healthy lifestyle" have one thing in common - the need for activity, ensuring the preservation and strengthening of health, expressed by medical, physical, environmental or any other form of human activity;

- people's activity is forming most effectively, when it satisfies their needs;

- optimization of health-saving activity depends on the state of mental health and the extent of the need in this kind of activity;
- the "cementing" basis that integrates all health-saving components can be characterized as health culture, belongs to a certain subject and is manifested through different kinds of activities.

Relying on these findings we conclude that a healthy lifestyle of an individual consists of three components: basic health culture (prolonged needs in healthsaving activities); health-saving activities (subcomponents) - physical, health, environmental, social, spiritual-moral, etc., conducted by people and closely related to their mental health; conditions that ensure the transfer of health culture to a healthy lifestyle. These components of a healthy lifestyle are interrelated and interdependent.

Health culture can be characterized as social competence in matters of health, stable necessities in healthy way of life, abilities and skills to satisfy them on the basis of health-saving activities.

The identified components and subcomponents of a healthy lifestyle can be productively used in the simulation of a model healthy-saving life activity, or, otherwise, in the development of a model healthy way of life.

The task to create such a model involves the reduction of the concept "healthy lifestyle" to the normative structure of its formation and the interpretation and its synthesis in the process of the formation of health-saving educational space (figure). 
Normative model of a healthy lifestyle.

Structure of a normative healthy lifestyle

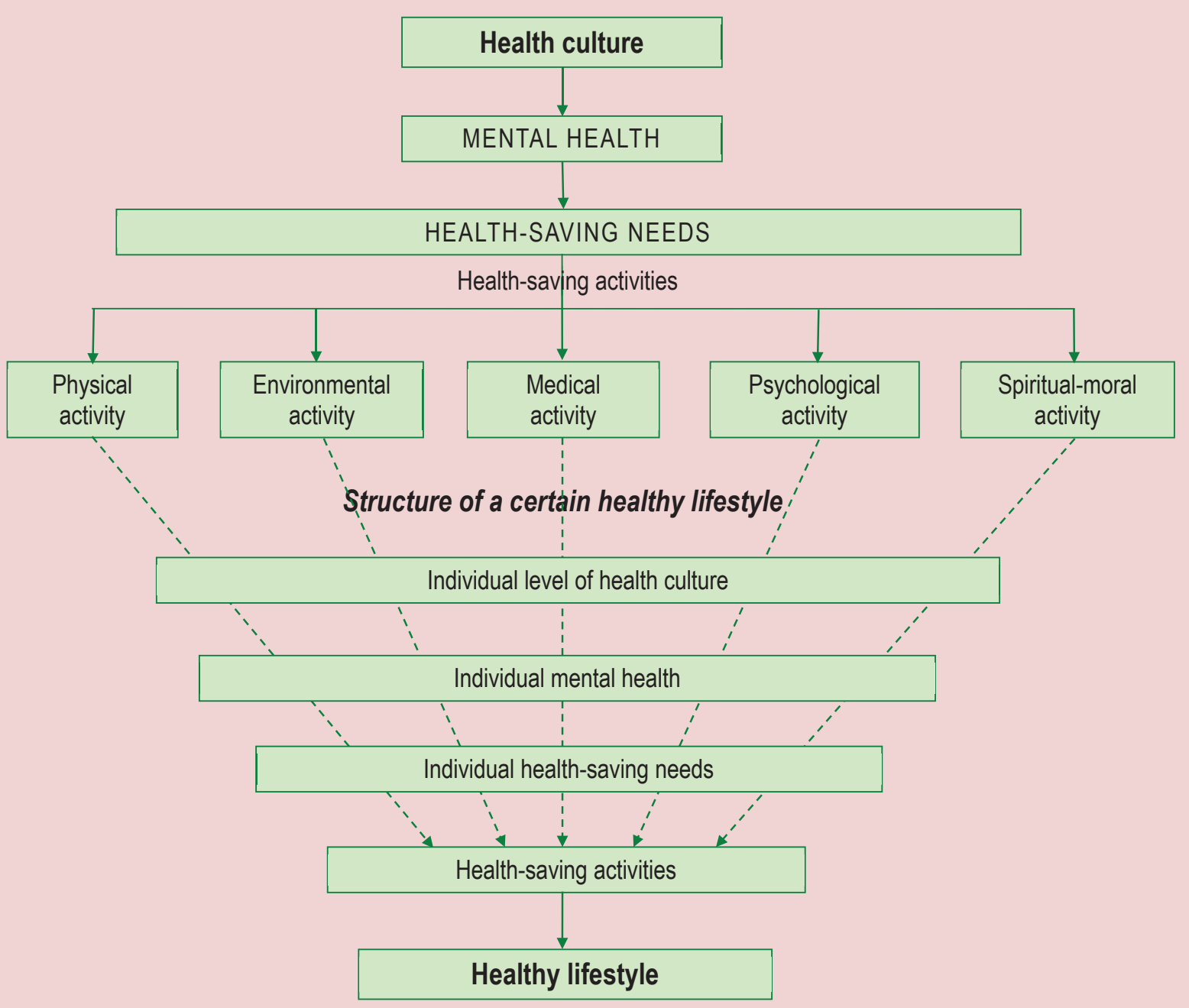


The normative model of a healthy lifestyle in terms of the pattern (ideal) of behavior is static. It is a comprehensive health-saving tool of an individual. This model reflects the optimized structure of a healthy lifestyle, which is realized in the form of an individual healthy lifestyle in everyday life. The proposed model suggests combing the effort of all society sectors and teaching and educating the younger generation to live a healthy life.

L.N. Voloshina considers activity as the key feature of a healthy child. She argues: "It is activity that ultimately determines health-promoting behavior and the state of health and ensures the transformation of children from irresponsible and passive objects in subjects of the health protection process who have a sense of responsibility, rights and duties" [5, p. 40].

When we speak about teaching healthy lifestyles, we mean, first of all, activities: physical, medical, environmental, psychological, spiritual-moral, which we define as basic.

As a result of the purposeful pedagogical process these activities become sustainable needs of the learner and then transfer into a healthy lifestyle. This algorithm to promote health-saving behavior can be characterized as a process of health culture formation.

Since the given activities ensure the preservation and enhancement of human health, they can also be called healthsaving activities and the acquired needs as health-saving needs. These needs can be reasonably characterized as formed subcomponents of health culture: physical culture, environmental culture, medical culture, psychological culture, spiritualmoral culture, etc.

Taking into account the stated above, we can give a general definition: a healthy lifestyle is a normative health-saving model of behavior, which is realized by a person in the society by means of satisfaction of health-saving needs through the appropriate optimized types of health-saving activities that are psychologically sound and ensure the preservation and the promotion of health. This way of life at the individual level is characterized as a healthy lifestyle and it expresses health culture.

This definition of a healthy lifestyle can serve as a single normative concept for all sectors of society involved in the HSS formation process.

The basis for this conclusion is the following:

- this definition takes into account all the considered views of scientists on the concept "healthy lifestyle";

- addresses pedagogical questions: what to teach pupils so that they can realize health-saving activity and what quality people acquire as a result of system pedagogical influence;

- allows all society sectors responsible for population' health to engage in the process of healthy lifestyle formation by teaching health-saving activities: physical, environmental, medical, psychological, spiritual-moral and others; 
- can become, according to the synergetic approach, a topology for the initial impact, be an attractor for the development of health-promoting activities and play a crucial role in achieving the objectives of the formation of health saving educational space.

The definition of "health", given by WHO, presupposes that the achievement of complete physical, mental and social well-being, the prevention of diseases and disabilities require certain knowledge about healthy life and systemic physical, medical, spiritual, environmental, social and other activities.

A person should have "health culture" and his/her life activity can be described as a healthy lifestyle.

The development of prolonged sustainable needs in health-saving types of activities should be considered as the formation of health culture.

\section{References}

1. Andreev Yu.A. Tri kita zdorov'ya [Three Pillars of Health]. Moscow: Fizkul'tura i sport, 1991. 332 p.

2. Bal'sevich V.K. Fizicheskaya podgotovka v sisteme vospitaniya kul'tury zdorovogo obraza zhizni cheloveka (metodologicheskii, ekologicheskii i organizatsionnyi aspekty) [Physical Training in the Education System of the Healthy Lifestyle Culture (Methodological, Environmental and Organizational Aspects)]. Teoriya i praktika fizicheskoi kul'tury [Theory and Practice of Physical Culture], 1990, no. 1.

3. Basova V.M. Formirovanie sotsial'noi kompetentnosti sel'skikh shkol'nikov: avtoref. dis. ... dok. ped. nauk [Formation of the Social Competence of Rural Students: Doctor of Pedagogy Dissertation Abstract]. Yaroslavl, 2004.

4. Vilenskii M.Ya., Avchinnikova S.O. Metodologicheskii analiz obshchego i osobennogo v ponyatiyakh "zdorovyi obraz zhizni" i "zdorovyi stil' zhizni": voprosy teorii [Methodological Analysis of the Differences and Similarities in the Concepts of "Healthy Way of Life" and "Healthy Style of Life": Theoretical Issues]. Teoriya i praktika fizicheskoi kul'tury [Theory and Practice of Physical Culture], 2004, no. 11, pp. 2-7.

5. Voloshina L.N. Razvitie zdorov'esberegayushchego obrazovatel'nogo prostranstva doshkol'nykh uchrezhdenii: metodologiya, teoriya, praktika: dis. ... dok. ped. nauk [The Development of Health Saving Educational Space of Preschool Institutions: Methodology, Theory, Practice: Doctor of Pedagogy Dissertation]. Yekaterinburg, 2006. $434 \mathrm{p}$.

6. Dahl V.I. Tolkovyi slovar' zhivogo velikorusskogo yazyka: $v 4 t$. [The Explanatory Dictionary of the Living Great Russian Language: in 4 Volumes]. Moscow: Rus. yaz., 1978, vol. 4.

7. Kasatkin V. Bolezn' kak nedostatok kul'tury [Disease as a Lack of Culture]. Chastnaya shkola [Private School], 1995, no. 4, pp. 106-112.

8. Kogan V.Z. Otnoshenie k zdorov'yu i puti ego adekvatnogo formirovaniya kak problema obshchestvennogo zdorov'ya [Attitude to Health and Ways of its Formation as a Problem of Public Health]. Obshchestvennoe zdorov'e i profilaktika zabolevanii [Public Health and Disease Prevention], 2006, no. 4, pp. 31-34.

9. Kokaeva I.Yu. Razvitie regional'nogo obrazovatel'nogo prostranstva kak faktor sokhraneniya i ukrepleniya zdorov'ya mladshikh shkol'nikov: dis. ... dok. ped. nauk [Development of Regional Educational Space as a Factor to Preserve and Strengthen Health of Junior Schoolchildren: Doctor of Pedagogics Dissertation]. Vladikavkaz, 2011.

10. Korobeinikov A.A. Aktual'naya evropeiskaya problema: vnedrenie zdorov'esberegayushchei pedagogiki [Topical European Issue: Implementation of Health-Saving Pedagogics]. Moscow, 2009. 264 p. 
11. Lisitsyn Yu.P. Obshchestvennoe zdorov'e i zdravookhranenie [Public Health and Health Care]. Moscow, 2002. $508 \mathrm{p}$.

12. Ozhegov S.I. Tolkovyi slovar' russkogo yazyka [Dictionary of the Russian Language]. Moscow: Russkii yazyk, 1987. 795 p.

13. Semashko N.A. Izbrannye proizvedeniya [Selected Works]. Second edition, revised and supplemented. Moscow: Meditsina, 1967. 379 p.

14. Solganik G.Ya. Stilisticheskii slovar' publitsista: okolo 6000 slov $i$ vyrazhenii [Stylistic Dictionary of a Publicist: About 6000 Words and Expressions]. Moscow: Russkii slovar', 1959. 650 p.

15. Solopov E.F. Kontseptsii sovremennogo estestvoznaniya: uchebnoe posobie dlya studentov vuzov [Concept for Modern Science: Textbook for University Students]. Moscow: VLADOS, 1998. 231 p.

16. Tatarnikova L.G. Pedagogicheskaya valeologiya [Pedagogical Valeology]. Saint Petersburg, 1997.356 p.

17. Fedorov A.I., Sharmanov S.B. Zdorov'e i povedenie shkol'nikov: Sotsial'no-pedagogicheskii monitoring zdorov'ya, fizicheskoi aktivnosti i obraza zhizni shkol'nikov [Health and Behavior of Schoolchildren: Socio-Pedagogical Monitoring of Health, Physical Activity and Lifestyle of Schoolchildren]. Moscow: ChGNOTs UO RAO, 2004. 88 p.

18. Chepurnykh E.E. Natsional'naya kontseptsiya okhrany zdorov'ya v sisteme obrazovaniya [National Health Concept in Education]. Magistr [Magister], 1999, no. 3, pp. 3-13.

19. Chumakov B.N. Valeologiya: kurs lektsii [Valeology: Course of Lectures]. Moscow: Ped. obshchestvo Rossii, 1999. 407 p.

\section{Cited works}

1. Andreev Yu.A. Three Pillars of Health. Moscow: Fizkul'tura i sport, 1991. 332 p.

2. Bal'sevich V.K. Physical Training in the Education System of the Healthy Lifestyle Culture (Methodological, Environmental and Organizational Aspects). Theory and Practice of Physical Culture, 1990, no. 1.

3. Basova V.M. Formation of the Social Competence of Rural Students: Doctor of Pedagogy Dissertation Abstract. Yaroslavl, 2004.

4. Vilenskii M.Ya., Avchinnikova S.O. Methodological Analysis of the Differences and Similarities in the Concepts of "Healthy Way of Life" and "Healthy Style of Life": Theoretical Issues. Theory and Practice of Physical Culture, 2004, no. 11, pp. 2-7.

5. Voloshina L.N. The Development of Health Saving Educational Space of Preschool Institutions: Methodology, Theory, Practice: Doctor of Pedagogy Dissertation. Yekaterinburg, 2006. 434 p.

6. Dahl V.I. The Explanatory Dictionary of the Living Great Russian Language: in 4 Volumes. Moscow : Rus. yaz., 1978, vol. 4.

7. Kasatkin V. Disease as a Lack of Culture. Private School, 1995, no. 4, pp. 106-112.

8. Kogan V.Z. Attitude to Health and Ways of its Formation as a Problem of Public Health. Public Health and Disease Prevention, 2006, no. 4, pp. 31-34.

9. Kokaeva I.Yu. Development of Regional Educational Space as a Factor to Preserve and Strengthen Health of Junior Schoolchildren: Doctor of Pedagogics Dissertation. Vladikavkaz, 2011.

10. Korobeinikov A.A. Topical European Issue: Implementation of Health-Saving Pedagogics. Moscow, 2009. $264 \mathrm{p}$.

11. Lisitsyn Yu.P. Public Health and Health Care. Moscow, 2002. 508 p.

12. Ozhegov S.I. Dictionary of the Russian Language. Moscow: Russkii yazyk, 1987. 795 p. 
13. Semashko N.A. Selected Works. Second edition, revised and supplemented. Moscow: Meditsina, 1967. $379 \mathrm{p}$.

14. Solganik G.Ya. Stylistic Dictionary of a Publicist: About 6000 Words and Expressions. Moscow: Russkii slovar', 1959. $650 \mathrm{p}$.

15. Solopov E.F. Concept for Modern Science: Textbook for University Students. Moscow: VLADOS, 1998. $231 \mathrm{p}$.

16. Tatarnikova L.G. Pedagogical Valeology. Saint Petersburg, 1997. 356 p.

17. Fedorov A.I., Sharmanov S.B. Health and Behavior of Schoolchildren: Socio-Pedagogical Monitoring of Health, Physical Activity and Lifestyle of Schoolchildren. Moscow : ChGNOTs UO RAO, 2004. 88 p.

18. Chepurnykh E.E. National Health Concept in Education. Magister, 1999, no. 3, pp. 3-13.

19. Chumakov B.N. Valeology: Course of Lectures. Moscow: Ped. obshchestvo Rossii, 1999. 407 p. 